\title{
Habermas and Markets
}

\author{
Timo Jütten
}

\section{Published in Constellations 20:4 (2013): 587-603.}

\section{Introduction}

Frankfurt School critical theory is a critical theory of modern capitalist societies. It is critical of capitalism because markets and the commodification of everyday life threaten forms of action, experience and social organization that members of the Frankfurt School at different times have thought to be preconditions of non-pathological individual and social life. Adorno's micrological analyses of damaged life in Minima Moralia are, of course, exemplary of this view. ${ }^{1}$ However, a similar view can be found in the work of Jürgen Habermas, who explained in an interview in 1977 that it "may be an idiosyncrasy of mine, or perhaps rather a legacy of the Frankfurt School, that, of all these side-effects [of capitalist crisis tendencies], I find myself most fascinated by those which jeopardize social and cultural integration - that is to say, the potential crises that initially assume socio-psychological form." ${ }^{2}$ Habermas' fascination with the socio-psychological costs of the market economy to those participating in it is poignant, because he also believes that the market economy is functionally necessary for the reproduction of modern societies.

In The Theory of Communicative Action (TCA) this dialectical understanding of markets comes to the fore. ${ }^{3}$ With the two-level concept of society the economic sphere, along with the administrative sphere of the modern state, becomes a functionally specified subsystem, differentiated out of the lifeworld and governed by the demands of system maintenance. This allows Habermas to conceptualise the dialectic of the market in terms of the relationship between lifeworld and system in the process of social modernization: one the one hand, the rationalization of the lifeworld and the displacement of material reproduction onto the economic system is an evolutionary gain in efficiency and steering capacity; on the other hand, this "capitalist pattern of modernization is marked by a deformation, a reification of 
the symbolic structures of the lifeworld under the imperatives of subsystems differentiated out via money and power and rendered self-sufficient" (TCA II, 283). In particular, Habermas suggests that the economy and the state administration "colonize" the lifeworld when they convert action coordination from consensus formation in language to market mechanisms or legal regulation (TCA II, 196), and thereby create social pathologies such as alienation, anomie and the loss of collective identity (TCA II, 140-48). 4

Habermas' conceptualization of modern society in The Theory of Communicative Action has been controversial. Much of this controversy has focused on the general meta-theoretical question of whether his social theory as a whole "cedes too much territory to systems theory" and therefore limits the scope of possible social criticism by methodological fiat. ${ }^{5}$ While this criticism concerns both the economy and the administrative institutions of the modern state, here I am particularly interested in Habermas' characterization of the market as a form of "norm-free sociality" (TCA II, 171, 307). Commentators have found it very difficult to specify what exactly is at stake in this characterization, but many have understood it to mean that individual behaviour in market settings, the institutional order of markets and their regulation are not governed by the moral and political norms that govern other forms of social interaction, and (therefore) are in some sense beyond the scope of moral and political appraisal. ${ }^{6}$ On this critical view, Habermas' diagnosis of the times in terms of the colonizing tendencies of the market comes at the cost of relinquishing the ideal of a rational and transparent organization of social labour and material reproduction that is constitutive of the Marxist tradition, and he seems to be unable to criticise morally blameworthy individual behaviour in the economic sphere. ${ }^{7}$

Thus in a 2009 interview Habermas expresses his hope that lessons will be learnt from the financial crisis in the language of The Theory of Communicative Action: "My hope is that the neoliberal agenda will no longer be accepted at face value but will be open to challenge. The whole program of subordinating the lifeworld to the imperatives of the market must be 
subjected to scrutiny." ${ }^{8}$ However, he seems adamant that the blame for the crisis should be squarely laid at the door of the political class, rather than the banks and other financial institutions. Why? "The speculators, too, were acting consistently within the established legal framework, according to the socially recognized logic of profit maximization. Politics turns itself into a laughing stock if it resorts to moralizing instead of relying upon the enforceable law of the democratic legislator. Politics, and not capitalism, is responsible for promoting the common good." 9 In the same interview Habermas calls compensation payments and bonuses for managers outrageous, which sounds a lot like a moral judgment, but also notes that the demand for caps on these payments and bonuses is merely symptomatic of a larger "legitimation crisis" of capitalism, which sounds a lot like a political diagnosis. ${ }^{10}$ Perhaps the uneasy relationship between the moral norms which we seem to invoke when we criticise bankers, hedge fond managers and overpaid executives, and the meta-theoretical norm according to which such moral judgments are inappropriate in the economic sphere, reflects something about the status of Habermas' critical theory as a diagnosis of the times.

While Habermas has characterized The Theory of Communicative Action as "hopelessly academic"11, he has also drawn attention to its "contemporary-historical motive", its timediagnostic thrust, which concerns Habermas' fear that the socio-psychological and cultural costs extracted by the stabilization of the economy through the bureaucratic welfare state give rise to social and political movements which question the value of social rationalization per se (TCA I, xli). Against these movements Habermas insists on the progressive potential inherent in modern societies and argues that it should be defended against the losses of freedom and meaning that modern subjects face from colonization and cultural impoverishment. The scope and limitations of such a defence, as Habermas saw them then, are hinted at in his 1985 answer to critics, "A Reply" (R). ${ }^{12}$ He defends the evolutionary value of system differentiation even in the face of the colonizing tendencies it engenders and suggests that, while the "defensive resteering" necessary to hold the systemic imperatives of 
the economic and bureaucratic spheres in check "will not be able to succeed without a radical and broadly effective democratization", "there is no longer much prospect of the democratic reshaping from within of a differentiated economic system" (R, 261, my emphasis).

Habermas' critical diagnosis of the times (Zeitdiagnose) in the 1980 s was informed by the crisis of the modern welfare state, which struggled to reconcile the economic imperatives of the private sector with the funding imperatives of a growing public sector while maintaining the legitimacy of welfare system in the light of criticisms from the Left and the Right. ${ }^{13}$ Three decades later, right-wing policies have eroded the welfare state significantly, and after the financial crisis it is now less clear than ever whether our economic and political systems serve our needs. To be sure, we still don't know whether the economy can be democratized from within, but the question of how to tame it has re-emerged as a moral and political question with new urgency.

If this is right, then distinguishing between the systematic elements of The Theory of Communicative Action and its time-diagnostic thrust becomes all-important. This is true both of Habermas' characterization of the market as norm-free and of the colonization thesis. In this paper I want to assess how convincing these arguments remain thirty years later. In the next section I re-examine Habermas' conception of the market in the light of some of the criticisms that have been levelled against it (II). My suggestion will be that while some of these criticisms are unfounded, we have good reasons to revise Habermas' views about norm-freedom. I then turn to the colonization thesis. Since Habermas limits himself to a brief analysis of juridification, I want to offer an analysis of commodification in terms of the colonization thesis, using the commodification of higher education as my case study (III). My conclusion will be that "colonization" remains a suggestive metaphor for our experience of social change today, and that Habermas' version of critical social theory remains timely, if amended (IV). 


\section{Norm-Free Sociality}

What is norm-free sociality? When Habermas characterizes a sphere of social action as norm-free, the intended contrast is with spheres of social action whose integration is governed by the norms of communicative action oriented toward mutual understanding. Thus when he writes that in modern capitalist societies "the market is the most important example of a norm-free regulation of cooperative contexts" (TCA II, 150, cf. 171), the intended contrast is with the regulation of cooperative contexts through consensus formation in language. More generally, Habermas distinguishes between two ways in which action systems may be integrated: whereas social integration works through consensus, "whether normatively guaranteed or communicatively achieved", system integration works through the "nonnormative steering of individual decisions not subjectively coordinated" (TCA II, 150). And, according to Habermas' theory of social evolution, “modern societies attain a level of system differentiation at which increasingly autonomous organizations are connected with one another via delinguistified media of communication: these systemic mechanisms - for example, money - steer a social intercourse that has been largely disconnected from norms and values, above all in those subsystems of purposive rational economic and administrative action that, on Weber's diagnosis, have become independent of their moral-political foundations" (TCA II, 154).

All objections to this characterization of the economy insist that "all economies...are moral economies." ${ }^{14}$ At least three such objections can be distinguished. My suggestion is that while these objections are only partially justified once the scope and diagnostic character of The Theory of Communicative Action is properly appreciated, we nevertheless have good reasons to take a different view on the substantive claims advanced. The objections concern: (1) the connection between types of action, types of action coordination and spheres of social action; (2) the role of moral and ethical considerations in the organization of labour; and (3) the possibility of moral appraisal in the economic sphere. 


\section{Types of action, types of action coordination and spheres of social action}

As we have seen, Habermas seems to endorse a conceptual connection between communicative action, action coordination through consensus formation in language and social integration on the one hand, and purposive action, action coordination through "nonnormative steering" and system integration on the other. However, according to some critics, such a connection must be implausible, since "every societal sphere of action exhibits a wealth of different types of action." 15 In particular, the economic and bureaucratic spheres rely on communicative as well as purposive rationality. ${ }^{16}$ In his 1985 "Reply," Habermas acknowledges that "the expression 'norm-free sociality' has led to misunderstandings" (R, 256) and offers this clarification:

It is obvious that commercial enterprises and government offices, indeed economic and political contexts as a whole make use of communicative action that is embedded in a normative framework. Leaving aside the fact that the functional contexts of media-steered subsystems cannot simply be marked off topologically from one another and made to match certain institutional complexes, my thesis amounts merely to the assertion that the integration of these action systems is in the final instance not based on the potential for social integration of communicative actions and the lifeworldly background thereof - and these systems make use of both. (R, 257)

This may seem like a major revision but, in fact, it merely restates what Habermas has already argued in The Theory of Communicative Action itself. To begin with, as "formally organised" subsystems, the economic and bureaucratic spheres are first constituted through law (TCA II, 309), and that means, in the case of the economic sphere, not only the private law of person, property and contract, but also the more substantive legal regulation of employment law, for example (cf. TCA II, 361). More importantly, Habermas also notes that "it is not only (or even chiefly) by way of the purposive-rational action of members that organizations resolve problems of self-maintenance. We may not assume, even in the case of the capitalist economic organization and the modern state organization, any linear dependency of organizational rationality on the rationality of members' actions" (TCA II, 306). Even in formally organised domains of action the mechanism of mutual understanding 
is merely "partially rescinded" (TCA II, 309), because all formal organisation relies on informal organisation. "Informal organization covers those legitimately regulated, innerorganizational relations that, notwithstanding the juridification of the framework, may be moralized. The lifeworlds of members, never completely husked away, penetrate here into the reality of organizations" (TCA II, 311). This explains, for example, why it is wrong to suggest that Habermas cannot explain how partners in economic exchange can trust each other - surely a requirement of economic exchange. ${ }^{17}$

To be sure, some critics have asked whether Habermas both can have his cake and eat it. Thus, according to Honneth, Habermas "cannot ascribe a moral infrastructure to the capitalist economic sphere, even if he sometimes admits that the modern organisation of labour is characterised by certain norms." This is because the very distinction between system and lifeworld depends on the fact that action coordination in the system occurs "only through the mediation of purposively-rational, strategic attitudes", while in the lifeworld it requires moral attitudes. ${ }^{18}$ However, for Habermas the distinctive feature of a system is its functionalist rationality, rather than the strategic attitudes that actors in it assume. Thus, while he insists that the distinction between system and lifeworld and their uncoupling is not only an analytic distinction but also a historical trend ( $\mathrm{R}, 257-58)$, he need not insist that communicative action is completely absent from the economic and bureaucratic spheres, just as he need not insist that strategic action is completely absent from the lifeworld. ${ }^{19}$ Rather, Habermas insists that communicative action "forfeits its validity basis" in that, as members of organizations, people "act communicatively only with reservation. They know they can have recourse to formal regulations, not only in exceptional but in routine cases; there is no necessity for achieving consensus by communicative means" (TCA II, 310-11). This distinction seems apt; it establishes a connection between two forms of action coordination and two spheres of social action in an ideal-typical fashion without reifying it. Functionalist imperatives constrain actors in the economic and bureaucratic systems, but they do not reduce actors' actions to purposively-rational, strategic attitudes. ${ }^{20}$ 


\section{Moral and ethical considerations in the organization of labour}

According to Habermas, the uncoupling of system and lifeworld and the displacement of the material reproduction of society onto the economic system is an advance from the perspective of social evolution. The increasing social complexity of modern societies threatens to overburden the lifeworld's capacity to steer social reproduction; hence, the replacement of mutual understanding in language with delinguistified steering media for the tasks of material reproduction is one of the "relief mechanisms" (cf. TCA II, 181) that free up lifeworld resources for the complex tasks of symbolic reproduction. ${ }^{21}$ Moreover, the "intrinsic evolutionary value exhibited per se by steering media such as money and power" shows itself in their greater efficiency in the material reproduction of society $(R, 261)$. As we have seen before, the contrast is with societies with a lower degree of social differentiation, where system integration and material reproduction remain tightly linked with social integration and symbolic reproduction. And nowhere is this clearer than in the sphere of social labour, where the commodification of labour power in the course of capitalist modernization destroyed those traditional lifeworlds, which were defined by this tight link of symbolic and material reproduction (Feudal societies are obvious examples). Habermas is very aware of this conflicted history, and his reconstruction of the normalization of wage labour in modern capitalist societies is very instructive.

According to this reconstruction, the uncoupling of lifeworld and system is accompanied by the formation of interchange relations between them. From the perspective of the lifeworld these interchange relations take the form of social roles. Thus, the "employment system regulates its interchanges with the lifeworld via the role of a member of an organization" (TCA II, 320), a role "constituted in legal form" (TCA II, 321). Actors who assume this role "detach themselves from lifeworld contexts and adapt themselves to formally organized domains of action", such as firms or corporations, where "they make some organization-specific contribution and are compensated for it (normally in the form of 
wages or salaries)" (TCA II, 321). From the perspective of the system the actors' concrete labour is transformed into abstract labour as input and exchanged for wages as output (TCA II, 322). Habermas acknowledges that the emergence of wage labour is a revolutionary change in the organization of social labour and that its eventual normalization was preceded by countless social struggles. However, he insists that "the new organizational forms gained wide acceptance and considerable permanency on the strength of their greater effectiveness and superior level of integration." More specifically, he insists that the "functionalist rationality" of the capitalist mode of production consists in the fact that it "can better fulfill the tasks of materially reproducing the lifeworld" than the Feudal mode of production could (TCA II, 321). This is particularly true in the social-welfare state.

In the social-welfare state, the roles provided by the occupational system become, so to speak, normalized. Within the framework of post-traditional lifeworlds, the structural differentiation of employment within organizations is no foreign element in any case; the burdens resulting from the character of heteronomously determined work are made at least subjectively bearable - if not through "humanizing" the workplace, through providing monetary rewards and legally guaranteed securities and are largely headed off in this way, along with other disadvantages and risks stemming from the status of workers and employees. (TCA II, 349)

Finally, Habermas suggests that "the role of employee loses its debilitating proletarian features" as a result of the welfare-state compromise (TCA II, 349). From the perspective of a critical social theory the question remains, however, whether "heteronomously determined work" is the price to be paid for improved standards of living and the promise of social security.

Recent writing in critical theory suggests that the questions of meaningful work and the democratic organization of social labour have not entirely disappeared from the ambit of social criticism. And some of this writing takes Habermas' seeming acquiescence to heteronomously determined work as its starting point. ${ }^{22}$ Thus according to Keith Breen, Habermas' characterization of the market "veils important moral-ethical counterarguments to market capitalism, one of the most significant being that under capitalism the productive capacities of human beings suffer avertable distortion." Since Habermas justifies the current 
organization of labour in terms of its efficiency in dealing with systemic complexity, he denies any importance to the character of human relationships in production and the potential emancipatory impact of work. As a result, "[t]he injustices, hardships, and drudgery suffered by men and women in their working lives are therefore no longer attributable to human agency and deliberate design, but issue instead from a reified and immutable logic.”23 In a similar vein, Honneth argues that Habermas' characterization of the economic sphere as norm-free makes it impossible to problematize the quality of work in critical social theory. However, unlike Breen, Honneth is acutely aware of the limits of any attempt to locate the emancipatory potential of work in the organic or autonomous character of production considered as craft. Not all necessary work can have this character, and the normative dimension of work in the economic sphere therefore must concern the social organization of labour, rather than its intrinsic character. ${ }^{24}$ Honneth's criticism of Habermas can now be stated more precisely than in $\S I I .1$ : if it can be shown that capitalist labour markets functionally require moral norms, if labour markets must be able to integrate socially as well as systemically, then Habermas' distinction between lifeworld and system as spheres of social action is redundant, and it is possible to criticize contemporary work practices in terms of these moral norms. ${ }^{25}$ What are these norms?

Honneth draws on Hegel and Durkheim in order to specify the norms that would legitimize the modern market economy. From Hegel he takes the idea that the legitimacy of capitalism depends on its ability to meet two normative conditions: first, it must make it possible for individuals to secure through their labour the necessary means of subsistence for themselves and their families at an adequate level; second, it must make it possible for individual workers to be socially recognized as making through their labour a contribution to the common good. ${ }^{26}$ From Durkheim Honneth takes the idea that the contribution of the market economy to social integration must take the form of a particular kind of solidarity, organic solidarity, which obtains when workers experience their labour as a "joint, cooperative effort for the common good." ${ }^{27}$ And it is a precondition of organic solidarity that 
the social division of labour is fair and transparent, so that individual workers can comprehend their own role and that of others in the system of production. Of course, Honneth is aware of the fact that modern market economies and their labour markets rarely meet Hegel's and Durkheim's conditions. However, he argues that they retain their critical force. In other words, Honneth can acknowledge that today's deregulated labour markets do not meet the normative conditions that would legitimize the market economy, but insist that these conditions can be mobilized as "moral resources" in order to question the existing economic arrangements. For present purposes Honneth's central claim is that this normative perspective on the organization of labour and the legitimacy of the market economy emerges only if we analyze the economy as a sphere of social integration rather than of system integration..$^{28}$

I am very sympathetic to the substance of Honneth's argument, and I expect most critical theorists are. However, the question is whether the critical force of these arguments really is not available to Habermas because of his reliance on the two-level concept of society. Presumably the question of the legitimacy of the market economy arises, on Habermas' conception of it, when it is uncoupled from the lifeworld and the interchange relations between the economic system and the lifeworld are first institutionalized (or subsequently re-institutionalized as the relationship between system and lifeworld changes). As we have seen, on his interpretation historical struggles about the commodification of labour and the development of the employee role have indeed taken place, and they have been pacified, at least in Germany ${ }^{29}$, because the rise of the social-welfare state has provided institutional safeguards against the risks unemployment and impoverishment. This is a substantive claim of social explanation, rather than the result of a methodological decision, and, most importantly, it suggests that the process of uncoupling is not irreversible, as Habermas explicitly notes. $3^{30}$ 
In fact, Habermas' time-diagnosis in The Theory of Communicative Action and his 1984 lecture on the crisis of the welfare state suggests that the relationship between the economy, the state and the lifeworld is fraught already. ${ }^{31}$ As is well known, Habermas is very aware of the inherent limits to social-welfare provision. Most importantly, the welfare state no longer manages to secure full employment, and the unemployed are marginalized socially, economically and politically despite the material support that they continue to receive. And in the last thirty years the situation has deteriorated significantly. As observers of German politics know, the current low unemployment figures conceal the deregulation of labour markets and the casualization of labour at an unprecedented scale that introduced phenomena such as the working poor and people working multiple jobs into the German labour market. Structural changes such as these have the potential to re-politicize labour.

Of course, it is an open question whether such a re-politicization of labour would make it possible for modern societies to meet the normative conditions of a legitimate market economy, as Honneth sees them. In particular, it is questionable whether complex modern economies can exhibit the features of organic solidarity - fairness and transparency - that would enable workers to experience their labour as a "joint, cooperative effort for the common good." As we have seen already, Habermas expresses such skepticism about the democratization of labour, not least because of the functionalist constraints of the economic system..$^{32}$ Instead he focuses on democratic resources in the lifeworld:

We are faced with the problem of how capabilities for self-organization can be developed to such an extent within autonomous public spheres that [a] radical democratic process of will-formation can come to have a decisive impact on the regulatory mechanisms and marginal conditions of media-steered subsystems in a lifeworld oriented toward use values, toward ends in general. This task involves holding the systemic imperatives of an interventionist state apparatus and those of an economic system in check, and is formulated in defensive terms. Yet, this defensive resteering will not be able to succeed without a radical and broadly effective democratization. (R, 261)

To be sure, one reason why Habermas is worried about locating the normative foundations of social criticism in the "utopian ideal of a society based on social labour" is the fact that the 
active labour force is a shrinking constituency in Western European societies. 33 Nevertheless, as long as a significant proportion of people do contribute to society through their labour, and as long as meaningful work is an important part of human flourishing, critical theorists should remain worried about the character of that work, and this might require its repoliticization in some sense. Perhaps Habermas is too sanguine here; but it seems to me that this is due to a substantive sociological judgment and not to his choice of methodology. ${ }^{34}$

\section{Moral appraisal in the economic sphere}

The financial crisis has focused attention on moral responsibility in the market economy. As we have seen in §I, Habermas' own comments are at best ambivalent. On the one hand, he insists that the neoliberal agenda needs to be attacked, and he seems outraged at the bloated bonuses received by bankers and other executives. On the other hand, he insists that they "were acting consistently within the established legal framework, according to the socially recognized logic of profit maximization." 35 And, presumably, that includes bloated pay and bonuses. Habermas' proposed solution is better regulation, and this is surely right, but he says surprisingly little about the blameworthy behaviour of individuals. This silence is of course closely related to the characterization of the market as norm-free. On this characterization actors in the economic sphere simply do not draw on the "moral resources" that are available to them in the lifeworld in order to evaluate individual conduct. In The Theory of Communicative Action Habermas uses language reminiscent of Lukács in order to describe the phenomenology of economic and bureaucratic action. "Members behave toward formally organized action systems, steered via processes of exchange and power, as toward a block of quasi-natural reality; within these media-steered subsystems society congeals into a second nature" (TCA II, 154, cf. 173). The reason for this reification of consciousness is that in the economic and bureaucratic spheres "[n]orm-conformative attitudes and identityforming social memberships are neither necessary nor possible...they are made peripheral instead" (TCA II, 154). In economic action subjects move from an orientation toward mutual understanding to a strategic attitude in which they pursue their own goals, rather than 
collectively agreed goals, through their responses to price signals. Economic action is thereby "ethically neutralized," because "normatively embedded interactions are turned into successoriented transactions among private legal subjects" (TCA II, 178).

As Habermas also points out, one manifestation of this ethical neutralization is the disappearance of individual responsibility from the economic sphere.

Delinguistified media of communication such as money and power, connect up interactions in space and time into more and more complex networks that no one has to comprehend or be responsible for. If by 'responsibility' we mean that one orients one's actions to criticizable validity claims, then a 'deworlded' coordination of action that is unhinged from communicatively established consensus does not require that participants be responsible actors. (TCA II, 184)

In the extreme case, personal responsibility is not merely watered down because the complex transactions of modern economies make it impossible to anticipate all the consequences of one's actions, ${ }^{36}$ but also because actors do not orient their actions to criticizable validity claims. In other words, action is not constrained by the possible agreement of others, as action oriented toward mutual understanding is. Clearly, moral responsibility cannot be attributed to agents, if a form of action does not require that they orient themselves with respect to the claims that others may have on them. To put it in a slogan: for Habermas, business ethics is not an oxymoron but a category mistake. ${ }^{37}$

However, it is far from obvious whether this disappearance of responsibility in the economic sphere is irreversible. Recall that it is one of Habermas' aims in The Theory of Communicative Action to show that the rationalization of the lifeworld and the uncoupling of lifeworld and system do not necessarily lead to social pathologies, such as alienation, anomie and the loss of collective identity (cf. TCA II, 140-48). More precisely, it does not lead to such pathologies if "differentiating between system and lifeworld and reproducing some kind of modern economy and political state are in the general interest of all those who participate in a modern lifeworld and have the corresponding postconventional moral and cultural collective identities that it presupposes." ${ }^{8} 8$ As we have seen in §II.2, in the case of the 
commodification of labour this took the form of showing that as long as certain conditions were met (the welfare-state protections against unemployment, health care and pension provisions amongst others), members of modern societies have accepted the legitimacy of the employment system despite "heteronomously determined work." However, we have also seen that a re-politicization of labour remains possible, if these conditions change. According to a parallel argument we can assume that the legitimacy of the market economy as a sphere of social action in which individuals may pursue their subjective ends in a self-interested way without regard to others' interests is dependent upon the continuous belief that this is the best way of organizing the material reproduction of society in terms of efficiency and fairness. This belief can be shaken in at least two ways. On the one hand, systemic failure can convince us that we must reform the "basic structure" of the economy in order to prevent future crises. However, on the other hand, we can also notice that reckless and immoral behaviour of particular individuals and corporations has exacerbated the crisis; not only have some exploited and entrapped others for personal or corporate gain, but some corporations have knowingly put the entire financial system at risk. Perhaps one lesson of the financial crisis is that it is insufficient for the background rules or the "basic structure" of the economy to be fair, whereas action within the economic sphere is beyond moral appraisal. As G.A. Cohen has argued convincingly in a different context, for a society to be just it is not sufficient that its basic structure is just, action within that structure must be just, too. ${ }^{39}$ From a Habermasian perspective the obvious danger of immoral behaviour in the market is a breakdown in social solidarity. Contrary to what Habermas suggests in the 2009 interview, people are not merely populist when they criticize bloated bonuses and pay, they protest against the fact that some become rich on the back of others' poverty, and that some people's livelihoods have been lost in order to make rich people richer.

If this is right, then the economy is not norm-free, because its legitimacy depends on its ability to organize the material reproduction of society efficiently and fairly. This is not to say that agents' individual choices must be coordinated centrally, democratically or otherwise. 
Habermas is right to be skeptical about the prospects of radical democratic self-organization. But it means that those who willfully or recklessly put this ability at risk should be criticized: we need a theory of moral appraisal in the market as well as a theory of the just basic structure. Perhaps this indicates a future research direction for critical theory.

\section{The Colonization Thesis: A Case Study}

The colonization thesis is the central time-diagnostic claim that Habermas advances in The Theory of Communicative Action in order to grasp the potentially destructive power of the market. As we have seen, according to Habermas, the process of social rationalization leads to a dialectic of enlightenment or a paradox of modernity (cf. TCA I, xl), which consists in the fact that "the rationalization of the lifeworld makes possible a heightening of systemic complexity, which becomes so hypertrophied that it unleashes system imperatives that burst the capacity of the lifeworld they instrumentalize" (TCA II, 155). In the light of this development the colonization thesis is the claim that "[i]n the end, systemic mechanisms suppress forms of social integration even in those areas where a consensus-dependent coordination of action cannot be replaced, that is, where the symbolic reproduction of the lifeworld is at stake. In these areas, the mediatization of the lifeworld assumes the form of a colonization" (TCA II, 196). I have argued elsewhere that the "cannot" in this passage is ambiguous; it can indicate a functionalist claim or a claim about normative expectations (about a particular social practice or institution)..$^{40}$ In my view, the latter view is correct. To be sure, mediatization becomes colonization when money and power encroach upon processes of symbolic reproduction (leading to social pathologies), but this colonization is experienced as a normative wrong, because it violates legitimate expectations about the scope and limits of such an encroachment relative to the purposes or integrity of the colonized practice or institution. Thus when Habermas points to the real conflict between a "strictly pedagogical approach to instruction" and "the economic system-imperative to uncouple the school system from the fundamental right to education and to close-circuit it with the employment system" (TCA II, 371), he points to a normative conflict about the value 
of education in our society and not merely to the danger of its dysfunctional symbolic reproduction..$^{41}$ In the remainder of this paper I want to take my lead from Habermas' diagnosis of colonization and offer an example of commodification-as-colonization, the commodification of higher education. I hope to illuminate the diagnostic strength of Habermasian critical theory by showing how it can make sense of this process.

\section{The commodification of higher education}

The discussion of higher education in terms of system and lifeworld is not alien to Habermas. In a 1986 lecture he describes how the "idea of the university" as Humboldt, Schelling and Schleiermacher conceived of it is mobilized again and again against a system of higher education that "has become functionally autonomous, and which is less and less in need of normative integration in the minds of professors and students the more it comes to be steered by systemic mechanisms and oriented to the environments of the economy and administrative planning through the production by the individual disciplines of technically usable information and professional qualifications." 42 According to the classical idea, the university has a central place in the symbolic reproduction of the lifeworld, because the philosophical reflection at the heart of science and scholarship shapes culture as a whole and serves the purposes of enlightenment and emancipation. And while this idea was perhaps always naïve, and its ambitious aims were never realized, there is a kernel of truth in it, because "the learning processes that take place within the university not only enter into an exchange with the economy and administration but also stand in an inner relationship to the functions through which the lifeworld reproduces itself.” ${ }^{43}$ They socialize lifeworld members into the scientific mode of thought, contribute to social and political discourses and further the hermeneutic self-understanding of the culture as a whole. Above all, Habermas stresses the communicative dimension of academic practice, and the contribution that this practice makes to society as a whole.

The egalitarian and universalistic content of its forms of argumentation expresses only the norms of scientific and scholarly activity, not those of society as a whole. But they share emphatically in the communicative rationality in whose forms modern 
societies, that is, societies which are not fixed once and for all and which have no guiding images, must reach an understanding about themselves. 44

Many defenders of public higher education today defend it in similar terms to Habermas. In the wake of the Browne Report on the financing of higher education in the United Kingdom (2010), which conceives higher education as a private good, a number of academics in the humanities and the social sciences (but also some natural scientists) have argued that it should not be reduced to private benefits but seen as collectively valuable, both in monetary and in non-monetary terms. ${ }^{45}$ For example, Stefan Collini clearly assumes that the intrinsic goods brought about by scholarship in the humanities are not limited to those who pursue such scholarship, but are available more widely throughout society (though he thinks it unwise to use this argument in order to argue for the "usefulness" of the humanities). ${ }^{46}$ More specifically, Collini rejects the reduction of scholarship in the humanities to the production of useful knowledge or skills, even though he notes that such knowledge and skills often are produced through such scholarship:

[O]ne has to make, over and over again, the obvious point that a society does not educate the next generation in order for them to contribute to its economy. It educates them in order that they should extend and deepen their understanding of themselves and the world, acquiring, in the course of this form of growing up, kinds of knowledge and skills which will be useful in their eventual employment, but which will no more be the sum of their education than that employment will be the sum of their lives. 47

In fact, Collini recognizes that humanities scholarship serves the "preservation, cultivation, and transmission of a cultural tradition", that is, the processes that Habermas names cultural reproduction. ${ }^{48}$

Other critics point to the role of the public university in processes of social integration and socialization. John Holmwood argues that one important role of the university, considered as a public university, is to improve the quality of public debate and discussion. As social complexity grows, the role of expertise in public policy-making increases, but at the same time "expertise" itself becomes problematic: "The increasingly embedded character of 
expert knowledge within corporations and government serves to de-legitimate expertise precisely by these forms of associations." If public debate is not to be reduced to populism, the public university has a crucial role to play as an intellectual force whose claim to knowledge is not tainted by corporate or governmental interest. 49 If this is right, then the commodification of higher education corrupts its purposes in at least two ways. First, it opens up research and teaching to the imperatives of the market and relinquishes the independence that is the basis of its legitimacy. Second, the introduction of competition between universities through differentiated tuition fees "undermines the social mission of universities in terms of the democratization of higher education", because it will lead to a division between students from poorer backgrounds who will seek out cheaper, more vocationally oriented universities and more wealthy students who will seek out prestigious research universities charging higher fees. As Holmwood puts it: "It is systematic government policy designed to dismantle fifty years of educational policy that sought to establish education as a social right." $5^{\circ}$ As Diane Reay has shown, not only does this "education apartheid" exclude the less wealthy sectors of the population from the competition for the best jobs, it also excludes them from the ranks of the informed, critical public, reinforcing the existing "class apartheid" of British society $\cdot{ }^{51} \mathrm{It}$ is easy to see how the commodification of higher education will further erode solidarity and strengthen alienation and anomie amongst those willfully excluded from access to education and social mobility.

\section{Commodification as colonization}

Is the commodification of higher education best understood as a form of colonization? I believe that some its decisive characteristics speak in favour of the colonization thesis as a diagnostic tool. The history of the commodification of higher education broadly follows the history of colonization that Habermas sketches in The Theory of Communicative Action. "The thesis of internal colonization states that the subsystems of the economy and state become more and more complex as a consequence of capitalist growth, and penetrate ever deeper into the symbolic reproduction of the lifeworld" (TCA II, 367). In the case of the 
commodification of higher education (and other public services) it is possible to identify a historical trajectory whereby state investment in higher education has decreased, often in order to curtail public expenditure, at the same time as student numbers have risen dramatically, both because higher education was seen as the road to upward social mobility and because a highly educated workforce was seen as a prerequisite of further economic growth. Governments and universities have addressed the subsequent shortfall of higher education funding through a shift to a consumer model of higher education, whereby students (and their parents) fund their education privately and are supported indirectly by the state through a complex supporting web of government-secured loans and tax credits. The result of this model for universities is that they now compete for students in a market, and their ability to survive in that market depends on their academic and non-academic offerings satisfying student preferences. At the same time, universities have sought to insulate themselves from the vagaries of government support by seeking third-party funding for academic research and by seeking to exploit commercial opportunities presented by their research. $5^{2}$

If this is right, then the commodification of higher education is indeed driven by colonization. Universities are forced to compete in markets for students and research funding, because the imperatives of the economic subsystem leave them no other choice but to assimilate their behaviour to market imperatives. As a result, strategic attitudes oriented at market success replace communicative action oriented toward reaching cooperative goals in many areas of university policy, including student recruitment and curriculum planning and the choice of research topics. ${ }^{33}$ The purposes and integrity of academic teaching and research are put at risk by the pressure to compete in the market for students and research funding.

However, there is an important challenge to this view, which stresses the extent to which the commodification of higher education originates in the universities themselves. This 
challenge is initially an observation about the changing behaviour of US universities, in which both academics and professional staff have begun to pursue entrepreneurial goals of their own accord. ${ }^{54}$ But for present purposes the challenge goes to the heart of the colonization thesis, because the thesis suggests that markets are imposed upon lifeworld institutions from the outside. In evaluating this challenge it is very important to keep in mind that much of the current commodification of teaching and research is a response to the imperatives of the market. It is certainly true, for example, that English universities have come a long way in marketing higher education and the "student experience" that encapsulates it as a consumer good, and that many US universities aggressively pursue the commercial exploitation of their intellectual property, but I am inclined to interpret these trends as responses to colonization rather than as indicating the need for an alternative explanation.

Nevertheless, the scope and speed of the commodification of higher education raises an important question about acquiescence and resistance. According to Habermas' theory of social evolution we would expect the subjection of material reproduction to market norms to gain legitimacy over time, given the social-welfare guarantees discussed in $\S I I .2$, while the subjection of symbolic reproduction to commodification or juridification would evince "stubborn and possibly successful resistance" (TCA II, 351). But while the commodification of higher education in the UK has evinced some resistance, ranging from student demonstrations to the publication of a flurry of non-academic and academic pamphlets, manifestos and books, 55 there does not seem to be wider social resistance beyond those who have a current interest in higher education (students and academics). I want to suggest that Habermas' analysis of the fragmentation of consciousness is helpful in understanding this lack of resistance and, at the same time, points to the need of a new theory of ideology.

According to Habermas' theory of social rationalization, the product of ideology, false consciousness, is replaced by fragmented consciousness. ${ }^{6}$ In the process of the 
rationalization of the lifeworld traditional ideologies lose their power, but this does not render social organization transparent. Rather, the functional role of ideology, meeting the need for interpretation, is taken over by the absence of such interpretation. "The lifeworld is always constituted in the form of global knowledge intersubjectively shared by its members; thus, the desired equivalent for no longer available ideologies might simply consist in the fact that the everyday knowledge appearing in totalized form remains diffuse...Everyday consciousness is robbed of its power to synthesize; it becomes fragmented" (TCA II, 355). The differentiation of value spheres and the formation of expert cultures within these spheres make it impossible to view the lifeworld holistically, and this cultural impoverishment drains the lifeworld of the resources that its members need in order to reach understanding over their collective situation. As Habermas notes: "This communicative infrastructure is threatened by two interlocking, mutually reinforcing tendencies: systematically induced reification and cultural impoverishment" (TCA II, 327). Colonization and cultural impoverishment go hand in hand, because once the latter has impoverished the lifeworld of critical resources, "the imperatives of autonomous subsystems make their way into the lifeworld from the outside - like colonial masters coming into a tribal society - and force a process of assimilation upon it” (TCA II, 355).

On the one hand, this is a plausible picture of our current predicament: the colonization of the lifeworld is the result of systemic crises in media-steered systems, and it meets little resistance because cultural impoverishment has robbed us of the critical resources that would enable us to resist colonization; we are unfree because fragmented consciousness "blocks enlightenment by the mechanism of reification" (TCA II, 355). 57 On the other hand, it is an implausible picture: it does not accommodate the normative discourse of commodification that paves the way for colonization. It is the discourse of neoliberal ideology, according to which deregulation, privatization and competition are not merely necessary but also good, and according to which markets are not merely efficient but also promote freedom. On Habermas' account, it seems as if the economic imperatives trump 
lifeworld resistance because there are no normative resources on which lifeworld members can draw in order to resist them. But, in fact, economic imperatives also dominate because a neoliberal ideology actively furthers their cause. The pernicious influence of neoliberal ideology on public policy has been demonstrated..$^{8}$ We need a theory of ideology to resist it.

\section{Conclusion}

The purpose of this paper was to examine Habermas' conception of the market in The Theory of Communicative Action. I have divided this task into two main parts. In §II, I have examined in detail whether Habermas' characterization of the market as norm-free commits him to implausible claims about the relationship between types of action, types of action coordination and spheres of social action, whether it prevents him from recognizing the norms governing the social organization of labour, and whether it makes it impossible for him to conceive of the market as a moral sphere. I have suggested that where Habermas' arguments fail to convince, this seems due to Habermas' substantive social explanation rather than to his choice of methodology. In particular, I have suggested that the neoliberal turn in the last 30 years may lead to a repoliticization of labour, and that we need a theory of morality in the market.

In §III, I have argued that the colonization thesis is a plausible diagnostic tool and offered the commodification of higher education as an example. I have shown that it fits the pattern of commodification-as-colonization, but I also have suggested that we still need a theory of ideology. Overall, my feeling is that where Habermas' criticism of capitalism and markets is not as radical as many of us wish it were this is due to his pessimism about meaningful alternatives, rather than to an alleged methodological straightjacket of The Theory of Communicative Action.59 And I have made suggestions about where his theory should be amended. 
Timo Jütten is a Lecturer in Philosophy at the University of Essex, UK. He has published papers on critical social theory in the European Journal of Philosophy, Inquiry, the International Journal of Philosophical Studies and the Deutsche Zeitschrift für Philosophie.

\section{Notes}

${ }^{1}$ See Theodor W. Adorno, Minima Moralia: Reflections from Damaged Life, trans. Edmond Jephcott (London: Verso, 1997), is exemplary of this view. See also Axel Honneth, "A Physiognomy of the Capitalist Form of Life: A Sketch of Adorno's Social Theory," Constellations 12 (2005), 50-64.

2 "Ideologies and Society in the Post-War World," interview with Gad Freudenthal (1977), in Autonomy and Solidarity: Interviews with Jürgen Habermas, ed. Peter Dews (London: Verso, 1986), 43.

3 Jürgen Habermas, The Theory of Communicative Action, Volume 1: Reason and the Rationalization of Society, trans. Thomas McCarthy (Boston: Beacon Press, 1984), Volume 2: A Critique of Functionalist Reason, trans. Thomas McCarthy (Boston: Beacon Press, 1987).

Several commentators have noted the structural similarity between this dialectic and the Dialectic of Enlightenment. See, for example, Axel Honneth, The Critique of Power: Reflective Stages in a Critical Social Theory, trans. Kenneth Baynes (Cambridge MA: The MIT Press, 1991), 285. See also Maeve Cooke, Language and Reason: A Study of Habermas' Pragmatics (Cambridge MA: The MIT Press, 1994), 134-36.

4 See also my discussion of this "colonization thesis" in Timo Jütten, "The Colonization Thesis: Habermas on Reification," International Journal of Philosophical Studies 19 (2011), 701-27.

5 Thomas McCarthy, "Complexity and Democracy: or the Seducements of Systems Theory," in Communicative Action. Essays on Jürgen Habermas's Theory of Communicative Action, ed. Axel Honneth and Hans Joas, trans. Jeremy Gaines and Doris L. Jones (Cambridge MA: The MIT Press, 1991), 120. See also Hans Joas' paper, "The Unhappy Marriage of Hermeneutics and Functionalism," in the same volume.

${ }^{6}$ See, amongst many, Honneth, The Critique of Power, 298-99, 302.

7 Of course, the rational and transparent organization of social labour and material reproduction may be an unrealistic goal in modern market economies. However, it seems to remain an ideal against which the legitimacy of modern market economies is judged. See my discussion in §II.2.

8 Jürgen Habermas, "Afterword: Lessons of the Financial Crisis," in Europe: The Faltering Project, trans. Ciaran Cronin (Cambridge: Polity, 2009), 185-86.

9 Ibid., 184.

10 Ibid., 187.

${ }_{11}$ "The Dialectics of Rationalization," interview with Axel Honneth, Eberhard Knödler-Bunte and Arno Widmann (1981), in Autonomy and Solidarity: Interviews with Jürgen Habermas, ed. Peter Dews, 108.

${ }^{12}$ Habermas, "A Reply," in Communicative Action, ed. Axel Honneth and Hans Joas, 214-64.

${ }^{13}$ Cf. Jürgen Habermas, Legitimation Crisis, trans. Thomas McCarthy (Cambridge: Polity, 1988); Claus Offe, Contradictions of the Welfare State, ed. John Keane (London: Hutchinson, 1984). See also Andrew Arato \& Jean L. Cohen, Civil Society and Political Theory (Cambridge MA: The MIT Press, 1992), especially pp. 464-91.

${ }^{14}$ William James Booth, "The Idea of the Moral Economy," American Political Science Review 88 (1994), 662b. See also Russell Keat, "Every Economy is a Moral Economy," unpublished manuscript, University of Edinburgh (2004), available at www.russellkeat.net (last accessed 9 April 2013).

${ }_{15}$ Joas, "The Unhappy Marriage of Hermeneutics and Functionalism," 104. See also Honneth, The Critique of Power, 292-93, where he criticizes Habermas for reifying his analytic concepts.

${ }^{16}$ See Honneth, The Critique of Power, 298-99.

${ }^{17}$ See Keith Breen, "Work and Emancipatory Practice: Towards a Recovery of Human Beings' Productive Capacities," Res Publica 13 (2007), 388.

${ }_{18}$ Axel Honneth, “Arbeit und Anerkennung: Versuch einer Neubestimmung," Deutsche Zeitschrift für Philosophie 56 (2008), 333 .

19 "Despite the action-theoretic characterization of steering-media, the media-steered subsystems of other action domains cannot be demarcated in terms of action types. Strategic actions do not only occur here; and it is not only strategic actions that do occur here" ( $\mathrm{R}, 258)$.

${ }^{20}$ I am grateful to Maeve Cooke for pressing me to clarify this point. See also her discussion of this important distinction in Cooke, Language and Reason, 144-46.

${ }^{21}$ The second relief mechanism is the development of communication media that condense mutual understanding in language, such as prestige and influence (cf. TCA II, 181-85).

${ }^{22}$ See Breen, "Work and Emancipatory Practice," and Honneth, "Arbeit und Anerkennung." See also Nicholas H. Smith, "Work and the Struggle for Recognition," European Journal of Political Theory 8 (2009), 46-60, and Beate Roessler, "Meaningful Work: Arguments from Autonomy," The Journal of Political Philosophy 20 (2012), 71-93.

${ }^{23}$ Breen, "Work and Emancipatory Practice," 389, 391. Breen suggests that Alasdair Macintyre's concept of a practice is the key to recovering the emancipatory content of work.

${ }^{24}$ Honneth, "Arbeit und Anerkennung," 328, 330. This characterization of the normative dimension of work supersedes Honneth's earlier attempt to ascribe an intrinsic normative dimension to it. See Axel Honneth, "Work and Instrumental Action," in The Fragmented World of the Social: Essays in Social and Political Philosophy (New York: SUNY Press, 1995).

${ }_{25}$ Honneth, "Arbeit und Anerkennung," 333. Of course, it would still be possible to distinguish between the participant and observer perspectives on social action and its consequences (including unintended consequences).

${ }^{26}$ Ibid., 334-35.

${ }^{27}$ Ibid., 339 . 
${ }^{28}$ Ibid., 337, 341. See also Honneth's extensive discussion of the capitalist labour market in Axel Honneth, Das Recht der Freiheit. Grundriß einer demokratischen Sittlichkeit (Berlin: Suhrkamp, 2011), 410-70.

${ }_{29}$ Habermas tends to write about Western Europe, but in the light of the significant differences between European capitalisms it is probably better to read his time diagnoses as concerning primarily the German case. For discussion see, for example, Varieties of Capitalism: The Institutional Foundations of Comparative Advantage, ed. Peter Hall and David Soskice (Oxford: Oxford University Press, 2001).

${ }^{30}$ Habermas writes: “...my insistence on the intrinsic value for social evolution of systemically differentiated steering media should be no means be read to signify that I 'have to conceive of the gradual independence achieved by the capitalist economic system'... as being irreversible" ( $\mathrm{R}, 294$, note 92 ).

${ }^{31}$ See Jürgen Habermas, "The New Obscurity: The Crisis of the Welfare State and the Exhaustion of Utopian Energies," in: The New Conservatism, trans. Shierry Weber Nicholson (Cambridge MA: Polity, 1989).

${ }^{32}$ See my discussion at the end of §II.1. See also Arato \& Cohen, Civil Society and Political Theory, 415-17.

${ }_{33}$ See Habermas, "The Crisis of the Welfare State and the Exhaustion of Utopian Energies," 53.

34 I have limited my analysis to The Theory of Communicative Action and related writings. However, there are indications that Habermas' ambivalence toward the democratization of labour survives unchanged in Between Facts and Norms (1992). For discussion see William E. Forbarth, "Short-Circuit: A Critique of Habermas's Understanding of Law, Politics, and Economic Life," in: Habermas on Law and Democracy: Critical Exchanges, ed. Michael Rosenfeld and Andrew Arato (Berkeley: University of California Press, 1998).

35 Habermas, "Lessons of the Financial Crisis," 184.

${ }^{36}$ It is a complex question, and beyond the scope of this paper, how to deal with moral responsibility in case of unintended and not-anticipated consequences. My focus in the text is on cases of intentional wrongdoing. Thanks to Fabian Freyenhagen for pointing out this further complication.

${ }^{37}$ Like most slogans, this one is an exaggeration. Since the absence of responsibility is an extreme case, ethical considerations may be present in less extreme cases.

${ }^{8}$ Arato \& Cohen, Civil Society and Political Theory, 371-72.

39 See G.A. Cohen, "Where the Action Is: On the Site of Distributive Justice," Philosophy and Public Affairs 26 (1997), 3-30. Cohen's argument concerns Rawls' restriction of the application of the Difference Principle to the basic structure of society. He argues - convincingly in my view - that the personal is political in the sense that if a society is to be governed by an ethos of justice, the actions of individuals in that society must adhere to that ethos. I am grateful to Avia Pasternak for pointing out that Cohen's argument is relevant to mine.

${ }^{40}$ See Jütten, "The Colonization Thesis," 709-12.

${ }^{41}$ Ibid., 720.

${ }^{42}$ Jürgen Habermas, "The Idea of the University: Learning Processes," in: The New Conservatism, trans. Shierry Weber Nicholsen, 105f.

43 Ibid., 122.

44 Ibid., 125.

45 Education is probably best seen as a merit good, since it "helps the individual who acquires it - including in rival situations, such as beating other applicants for a job - but there are also general gains from there being an educated population in, for example, the higher levels of economic activities in which an educated society can engage...Education is also non-rival if we think of it as giving access to knowledge, cultural and scientific appreciation" (Colin Crouch, The Strange Non-Death of Neoliberalism [Cambridge: Polity, 2011], 37).

${ }^{46}$ Stefan Collini, What Are Universities For? (London: Penguin, 2012), 88. Collini also suggests that there is a lot more appreciation of this non-monetary benefit of scholarship among non-scholars in the wider public than policy makers assume. 47 Ibid., 91.

${ }_{48}^{8}$ Ibid. However, he believes that this justifies only a small number of outstanding institutions devoted to that task.

${ }^{49}$ John Holmwood, "The Idea of a Public University," in: A Manifesto for the Public University, ed. John Holmwood (London: Bloomsbury Academic, 2011), 25. Holmwood draws on John Dewey's famous analysis of the problems of the public.

$5^{\circ}$ Ibid., 18, 19.

${ }^{51}$ Diane Reay, "Universities and the Reproduction of Inequality," in: A Manifesto for the Public University, ed. John Holmwood, 117,121 . Reay shows how the commodification of higher education will lead to upper and upper-middle classes who float free of connection with the less wealthy parts of society.

${ }^{2}$ There are many sources for this trajectory, with minor variations. For the US case, see, for example, Derek Bok, Universities in the Marketplace: The Commercialization of Higher Education (Princeton: Princeton University Press, 2003), Sheila Slaughter and Gary Rhoades, Academic Capitalism and the New Economy: Markets, State, and Higher Education (Baltimore: The John Hopkins University Press, 2004), Chapter 2, and "Academic Capitalism and the New Economy: Privatization as Shifting the Target of Public Subsidy in Higher Education," in: The University, State, and Market: The Political Economy of Globalization in the Americas, ed. Robert A. Rhoads and Carlos Alberto Torres (Stanford: Stanford University Press, 2006). For the British case, see, for example, Collini, What Are Universities For?, Chapter 2, William Locke, "False Economy? Multiple Markets, Reputational Hierarchy and Incremental Policymaking in UK Higher Education," in: Higher Education and the Market, ed. Roger Brown (London: Routledge, 2011), and also the Browne Report itself: Securing a Sustainable Future for Higher Education: Independent Review into Higher Education Funding and Student Finance (UK Department for Business, Innovation and Skills, 2010).

53 For evidence of this shift see Slaughter and Rhoades, Academic Capitalism and the New Economy, Chapter 7, and The Commodification of Academic Research, ed. Hans Radder (Pittsburgh: University of Pittsburgh Press, 2010), respectively.

${ }_{54}$ Thus Slaughter and Rhoades write: "We have come to see colleges and universities (and academic managers, professors, and other professionals within them) as actors initiating academic capitalism, not just as players being 'corporatized" (Academic Capitalism and the New Economy, 12).

55 In addition to Collini's book and the collection edited by Holmwood see also The Assault on Universities: A Manifesto for Resistance, ed. Michael Bailey and Des Freedman (London: Pluto, 2011).

${ }_{56}^{6}$ The relationship between the colonization thesis and the fragmentation of consciousness is complex. See Jütten, "The Colonization Thesis," 725, n. 28.

${ }^{57}$ For the conceptual connection between reification and unfreedom see Timo Jütten, "Verdinglichung und Freiheit," Deutsche Zeitschrift für Philosophie 59 (2011), 717-30.

${ }^{8}$ See, for example, Crouch, The Strange Non-Death of Neoliberalism, and David Harvey, A Brief History of Neoliberalism (Oxford: Oxford University Press, 2007). 
59 Many thanks to Maeve Cooke for written comments on an earlier draft of this paper and to Andrew Arato, Paul Bou-Habib, Bob Goodin, Fabian Freyenhagen, Avia Pasternak and David Strecker. Thanks also to the participants of a seminar organised by graduate students at the University of Essex in April 2012 and of the Philosophy and the Social Sciences Colloquium in Prague in May 2012, where I presented earlier drafts. 